\title{
Experimental Investigation on the Impact Resistance of Carbon Fibers Reinforced Coral Concrete
}

\author{
Bing Liu ${ }^{1,2}$, Jingkai Zhou ${ }^{1,2}$, Xiaoyan Wen ${ }^{1,2}$, Jianhua Guo ${ }^{1,2}$, Xuanyu Zhang ${ }^{1}$, \\ Zhiheng Deng $1,2, *(\mathbb{D})$ and Huailiang Wang ${ }^{1,2, *}$ \\ 1 College of Civil Engineering and Architecture, Guangxi University, Nanning 530004, China; \\ gxulb@alu.gxu.edu.cn (B.L.); gxu_zjk@163.com (J.Z.); gxu_wxy@163.com (X.W.); gxu_gjh@163.com (J.G.); \\ gxu_zxy@163.com (X.Z.) \\ 2 Key Laboratory of Disaster Prevention and Structural Safety of Ministry of Education, Nanning 530004, \\ China \\ * Correspondence: dengzh@gxu.edu.cn (Z.D.); whuailiang@gxu.edu.cn (H.W.)
}

Received: 25 October 2019; Accepted: 29 November 2019; Published: 2 December 2019

\begin{abstract}
In this study, the impact resistance of coral concrete with different carbon fiber (CF) dosages subjected to drop-weight impact test was investigated. For this purpose, three concrete strength grades (C20, C30, C40) and six CF dosages $(0.0 \%, 0.3 \%, 0.6 \%, 1.0 \%, 1.5 \%$, and $2.0 \%$ by weight of the binder) were considered, and a total of 18 groups of carbon fibers reinforced coral concrete (CFRCC) were cast. For each group, eight specimens were tested following the drop-weight impact test suggested by CECS 13. Then, the two-parameter Weibull distribution theory was adopted to statistically analyze the variations in experimental results. The results indicated that the addition of CFs could transform the failure pattern from obvious brittleness to relatively good ductility and improve the impact resistance of coral concrete. Moreover, the impact resistance of CFRCC increases with the CF dosage increasing. The statistical analysis showed that the probability distribution of the blow numbers at the initial crack and final failure of CFRCC approximately follows the two-parameter Weibull distribution.
\end{abstract}

Keywords: coral concrete; carbon fibers; impact resistance; drop-weight impact test; Weibull distribution

\section{Introduction}

The ocean is an essential space for the sustainable development of whole humans due to its abundant resources [1]. Recently, with the rapid development of society, the development and utilization of marine resources and the development of marine industry have received extensive attention [2,3]. Therefore, there are more and more island construction projects, which have led to a significant increase in demand for marine concrete [4,5]. In addition, the utilization of locally available resources on islands as materials to mix concrete has essential practical significance because it can solve the shortage of construction materials problem, shorten the construction period, and reduce costs for distant island reef construction projects $[1,6,7]$.

On the tropic islands, there are abundant coral reef resources [8]. Thus, the coral reef is a desired material for mixing marine concrete. Extensive researches have shown that it is feasible to use coral as the raw material of marine concrete [4,6,9-11]. Researchers call this concrete, which uses coral as aggregates, coral concrete $[4,6,12]$. Many researchers have conducted research on the various properties of coral concrete, such as the compressive strength [13-15], the tensile strength $[3,5,16]$, the elastic modulus [17-19], the durability [12,18,20], etc. However, the impact performance of coral concrete under impact loading has been rarely studied [21]. 
The impact resistance is recognized today as one of the significant properties of concrete used for civil engineering [22]. Many concrete elements may be subjected to low-velocity impact loads such as road pavements, breakwater, and precast concrete piles [21,23]. Therefore, it is especially important to understand and improve the impact resistance performance of coral concrete. Some studies indicated that the addition of fibers (such as steel fibers, polypropylene fibers, carbon fibers) could improve the impact resistance of concrete [24-27]. For example, Mastali et al. [27] found that, when incorporating carbon fibers (CFs) with a length of $30 \mathrm{~mm}$ and a volume fraction of $2.0 \%$, the impact resistance of concrete at initial crack and ultimate crack can be increased to 3 and 5 times that of the reference specimen, respectively. Recently, the application of CFs in concrete is more and more extensive due to its high corrosion resistance, low density, high tensile strength, and high elastic modulus [28-31]. Thus, in the present study, CFs are chosen as the enhancement material to enhance the impact resistance of coral concrete.

Several test methods, including explosive test, projectile test, Charpy pendulum test, split Hopkinson pressure bar (SHPB) test, and drop-weight impact test, have been suggested to study the impact resistance performance of fibers reinforced concrete [24,32-35]. Among them, the explosive test and projectile test are usually used for high-velocity impact test; the Charpy pendulum test, split Hopkinson pressure bar (SHPB) test, and drop-weight impact test can be used for low-velocity impact test, but the test devices for Charpy pendulum test and SHPB test are expensive, and the test steps are also complicated; the device for drop-weight impact test is not expensive and the test steps are also simple. Thus, the drop-weight impact test method has been widely adopted to low-velocity impact experiments by many researchers $[24,26,36]$. Thus, the drop-weight impact test method is also selected as the test method for studying the impact resistance performance of carbon fibers reinforced coral concrete (CFRCC) in this study.

The purpose of the present study is to investigate the impact resistance performance of CFRCC under impact loading. For this purpose, a total of eighteen CFRCC mixtures with three strength grades (C20, C30, C40) and six CF dosages $(0.0 \%, 0.3 \%, 0.6 \%, 1.0 \%, 1.5 \%, 2.0 \%$ by weight of the binder) were designed. Through the drop-weight impact test, the failure patterns, the blow numbers and impact energy at the initial crack and final failure of CFRCC were obtained. Based on the experimental results, the effect of CFs and concrete strength grade on the impact resistance of CFRCC was analyzed. Moreover, a statistical analysis was conducted to analyze the experimental results by the two-parameter Weibull distribution theory. The results of this study help extend the use of CFRCC and further understanding of the nature of the impact behavior of coral concrete.

\section{Materials and Methods}

\subsection{Raw Materials}

The binder was GB175 [37] Ordinary Portland P.O. 42.5 cement. Coral sand with a fineness modulus of 3.0 was used as the fine aggregates (Figure 1), while crushed coral stones (Figure 2) were used as coarse aggregates. Tables 1 and 2 showed the physical properties of those aggregates tested according to the code GB/T 17431 [38] (similar to the code of ASTM C330) and JGJ 52 [39] (similar to the code of ASTM C33), respectively. The chopped CFs (Figure 3) with a length of $10 \mathrm{~mm}$ and a diameter of $7.3 \mu \mathrm{m}$ were used in this study, which have an elastic modulus of $231 \mathrm{GPa}$, a tensile strength of $4558 \mathrm{MPa}$, an elongation at break of $2.05 \%$, and a density of $1820 \mathrm{~kg} / \mathrm{m}^{3}$. In order to obtain a good dispersion of CFs in the mixtures, hydroxypropyl methylcellulose (HPMC) and AGITAN P803 were used as dispersing agent and antifoaming agent, respectively. A QS-8020H Polycarboxylate Superplasticizer (SP) was used to enhance the workability. The mixing water was seawater taken from the sea in Guangxi Beibu Gulf. 


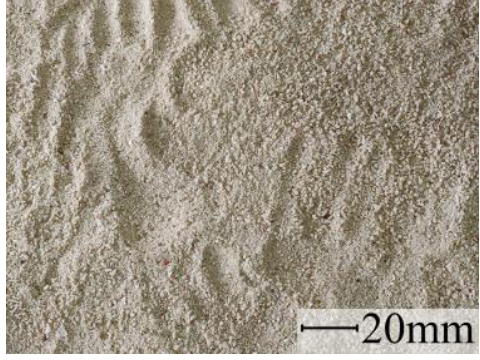

(a)

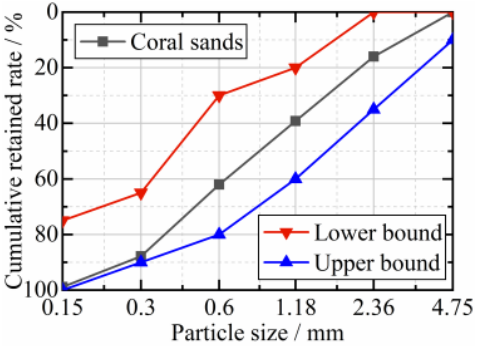

(b)

Figure 1. Coral fine aggregates: (a) appearance; (b) grading curve.

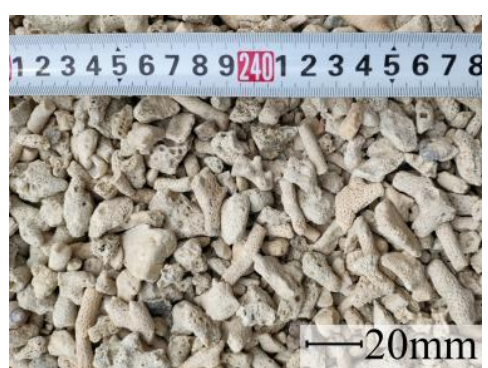

(a)

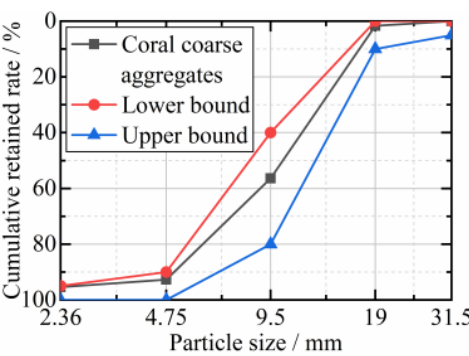

(b)

Figure 2. Coral coarse aggregates: (a) appearance; (b) grading curve.

Table 1. Physical properties of coral coarse aggregates.

\begin{tabular}{|c|c|c|c|c|c|c|c|c|}
\hline \multirow{2}{*}{$\begin{array}{c}\text { Bulk } \\
\text { Density } \\
\left(\mathrm{kg} / \mathrm{m}^{3}\right)\end{array}$} & \multirow{2}{*}{$\begin{array}{l}\text { Apparent } \\
\text { Density } \\
\left(\mathrm{kg} / \mathrm{m}^{3}\right)\end{array}$} & \multirow{2}{*}{$\begin{array}{c}\text { Void } \\
\text { Content } \\
(\%)\end{array}$} & \multicolumn{2}{|c|}{ Water Absorption/\% } & \multirow{2}{*}{$\begin{array}{c}\text { Water } \\
\text { Content } \\
(\%)\end{array}$} & \multirow{2}{*}{$\begin{array}{c}\text { Tube } \\
\text { Compressive } \\
\text { Strength } \\
\text { (MPa) }\end{array}$} & \multirow{2}{*}{$\begin{array}{c}\text { Dust } \\
\text { Content } \\
(\%)\end{array}$} & \multirow{2}{*}{$\begin{array}{l}\text { Particle } \\
\text { Shape } \\
\text { Factor }\end{array}$} \\
\hline & & & $1 \mathrm{~h}$ & $24 \mathrm{~h}$ & & & & \\
\hline 915 & 1841 & 50 & 8.5 & 11.0 & 2.6 & 3.1 & 2.9 & 2.4 \\
\hline
\end{tabular}

Table 2. Physical properties of coral fine aggregates.

\begin{tabular}{ccccccc}
\hline $\begin{array}{c}\text { Bulk Density } \\
\left(\mathbf{k g} / \mathbf{m}^{\mathbf{3}}\right)\end{array}$ & $\begin{array}{c}\text { Apparent Density } \\
\left(\mathbf{k g} / \mathbf{m}^{\mathbf{3}}\right)\end{array}$ & Graduation & $\begin{array}{c}\text { Fineness } \\
\text { Modulus }\end{array}$ & $\begin{array}{c}\text { Water } \\
\text { Content } \mathbf{( \% )}\end{array}$ & $\begin{array}{c}\text { Water } \\
\text { Absorption } \\
\mathbf{( \% )}\end{array}$ & $\begin{array}{c}\text { Dust } \\
\text { Content }\end{array}$ \\
\hline 1296 & 2707 & II & 3.0 & 2.9 & 3.7 & 0.5 \\
\hline
\end{tabular}

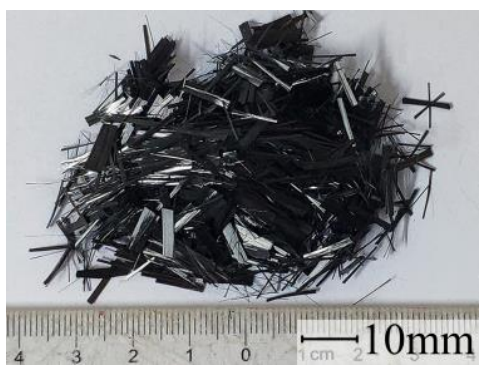

Figure 3. Chopped carbon fibers.

\subsection{Mix Proportions and Specimen Preparation}

The designed strength grades of CFRCC without CF addition were C20, C30, and C40, respectively. The basic mix proportions were designed according to JGJ 51 [40] and presented in Table 3. The CFs dosage were $0.0 \%, 0.3 \%, 0.6 \%, 1.0 \%, 1.5 \%, 2.0 \%$ by weight of the binder (cement). The usage of HPMC 
and P803 was $0.4 \%$ and $0.15 \%$ by weight of the binder, respectively. Some studies $[13,41,42]$ pointed out that preparation of coral concrete with pre-wetted coral coarse aggregates is beneficial for improving the compressive strength, improving the workability, reducing the self-shrinkage and dry shrinkage of coral concrete. Thus, the coral coarse aggregates have been pre-wetted before mixing. The procedure of mixing CRFCC is illustrated in Figure 4. After the uniform mixture was obtained, the stirred mixture was cast in molds and vibrated for about $30 \mathrm{~s}$ on a vibration table. For each mixture, three $100 \mathrm{~mm} \times$ $100 \mathrm{~mm} \times 100 \mathrm{~mm}$ cubes and two $150 \mathrm{~mm} \times 300 \mathrm{~mm}$ cylinders were cast. All cast specimens were cured at room temperature for $24 \mathrm{~h}$, then demolded and cured in a marine environment curing cabinet for $28 \mathrm{~d}$. The marine environment curing cabinet has a seawater spray device and several related sensors that can simulate the humidity of the real marine environment. Then, cube specimens conducted the cube compressive strength test following the code GB/T50081 [43] (similar to the code of ASTM C33, but the specimen used is cube specimen instead of cylindrical specimen) to obtain the cube compressive strength of each CFRCC mixtures (see Table 4), and each cylindrical specimen was cut into four discs of $150 \mathrm{~mm} \times(63 \pm 2) \mathrm{mm}$ for the drop-weight impact test.

Table 3. Coral concrete mix proportions

\begin{tabular}{ccccccc}
\hline $\begin{array}{c}\text { Strength } \\
\text { Grade }\end{array}$ & $\begin{array}{c}\text { Cement } \\
\mathbf{( k g )}\end{array}$ & Net W/C & $\begin{array}{c}\text { Net Water } \\
\mathbf{( k g})\end{array}$ & $\begin{array}{c}\text { Additional } \\
\text { Water } \\
\mathbf{( k g )}\end{array}$ & $\begin{array}{c}\text { Coral Coarse } \\
\text { Aggregates } \mathbf{( k g})\end{array}$ & $\begin{array}{c}\text { Coral Sand } \\
(\mathbf{k g})\end{array}$ \\
\hline CC20C00 & 380 & 0.53 & 200 & 5.8 & 774 & 674 \\
CC30C00 & 480 & 0.38 & 180 & 5.8 & 774 & 674 \\
CC40C00 & 650 & 0.28 & 180 & 5.8 & 774 & 674 \\
\hline
\end{tabular}

${ }^{1}$ Net $W / C=$ Net water/Cement.

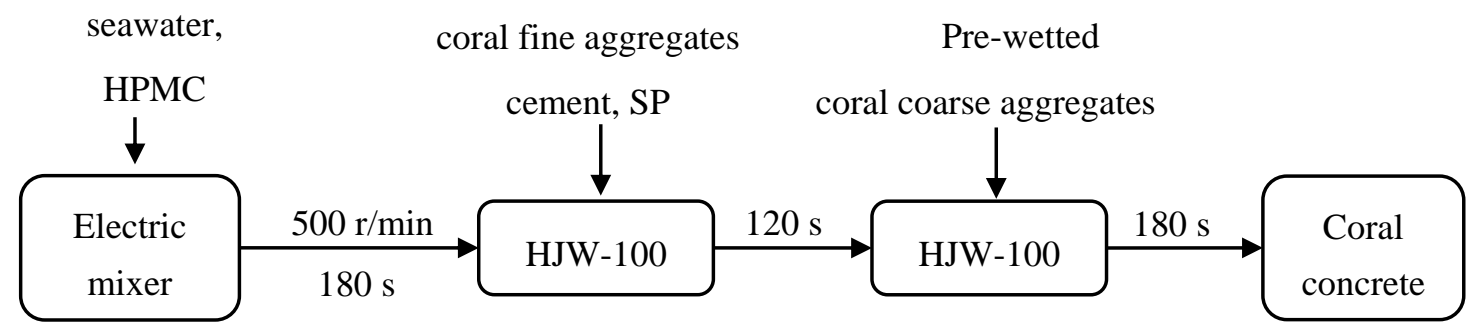

Figure 4. The process of the mixing method

\subsection{Impact Tests}

The impact test was conducted following the China CECS 13 [34] drop-weight impact test that was modified from the ACI 544 [44] suggested method. The details of the drop-weight impact test setup are illustrated in Figure 5. As shown in Figure 5, a steel hammer with a mass of $4.5 \mathrm{~kg}$ drops from a height of $500 \mathrm{~mm}$ on a steel ball with a diameter of $63 \mathrm{~mm}$ located on the central surface of the disc specimens. The number of blows causing the first visible crack was recorded as the initial crack resistance factor $\left(N_{1}\right)$, and the number of blows until the pieces of specimen touching three of the four steel lugs was recorded as the final failure resistance factor $\left(N_{2}\right)$. For each mixture, eight discs were tested, and the impact resistance was represented based on the average of eight specimens. The impact energy at initial crack and final failure were calculated by using the following equation:

$$
W_{i}=N_{i} \times \frac{1}{2} \times m \times v^{2}=N_{i} m g h,
$$

where $W_{i}$ is the impact energy (J); $N_{i}$ is the number of blows; $m$ is the weight of steel hammer with a mass of $4.5 \mathrm{~kg}$; $v$ is the velocity of the steel hammer $(\mathrm{m} / \mathrm{s}) ; g$ is the acceleration of gravity $\left(9.81 \mathrm{~m} / \mathrm{s}^{2}\right) ; h$ is the falling height of the steel hammer $(500 \mathrm{~mm})$; and $i=1,2$ is representing the initial crack and final failure, respectively. 
Table 4. Cube compressive strength.

\begin{tabular}{cccc}
\hline No. & $\begin{array}{c}\text { Average } \\
(\mathbf{M P a})\end{array}$ & Standard Deviation & Coefficient of Variation \\
\hline CC20C00 & 21.0 & 3.08 & 0.15 \\
CC20C03 & 21.7 & 1.83 & 0.08 \\
CC20C06 & 22.9 & 1.34 & 0.06 \\
CC20C10 & 23.0 & 2.02 & 0.09 \\
CC20C15 & 24.5 & 2.12 & 0.09 \\
CC20C20 & 24.7 & 0.42 & 0.02 \\
CC30C00 & 33.4 & 0.91 & 0.03 \\
CC30C03 & 33.9 & 2.52 & 0.07 \\
CC30C06 & 35.2 & 3.56 & 0.10 \\
CC30C10 & 35.3 & 1.56 & 0.04 \\
CC30C15 & 36.4 & 1.39 & 0.04 \\
CC30C20 & 36.6 & 4.69 & 0.13 \\
CC40C00 & 42.7 & 4.91 & 0.11 \\
CC40C03 & 44.3 & 2.16 & 0.05 \\
CC40C06 & 44.7 & 1.04 & 0.02 \\
CC40C10 & 45.1 & 2.03 & 0.05 \\
CC40C15 & 46.4 & 2.77 & 0.06 \\
CC40C20 & 47.5 & 2.59 & 0.05 \\
\hline
\end{tabular}

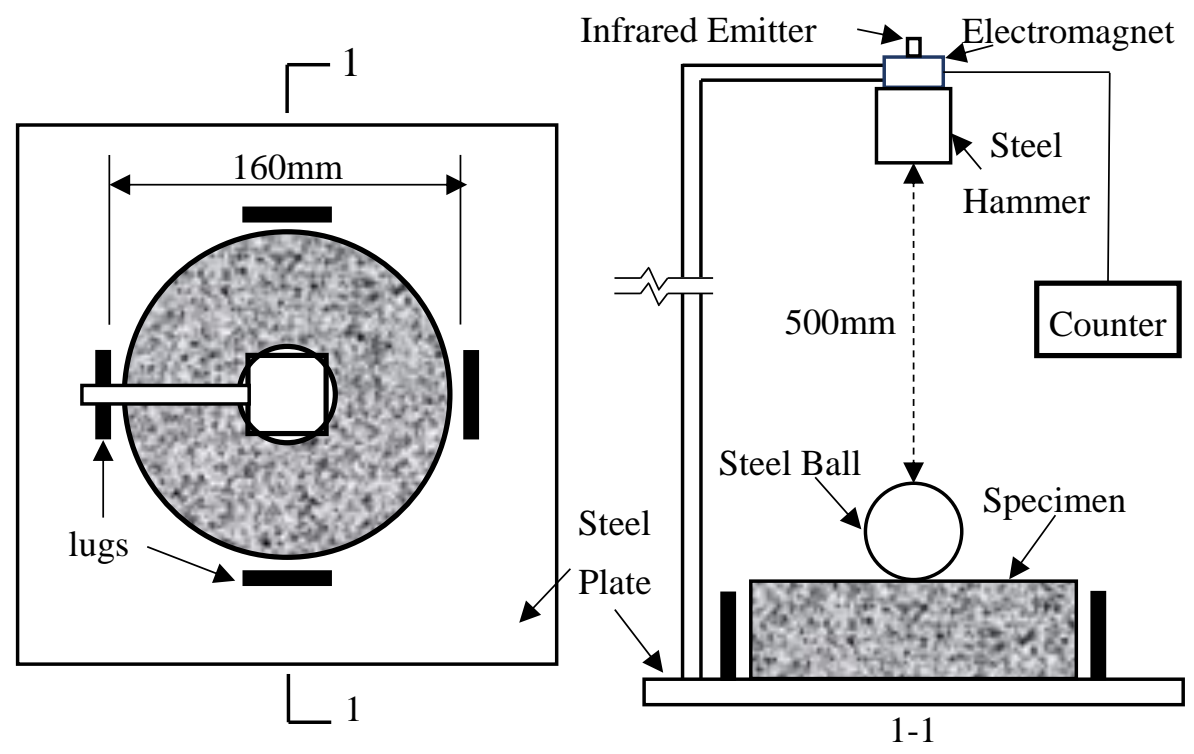

Figure 5. The details of the drop-weight impact test setup.

\section{Results and Discussion}

\subsection{Failure Patterns under Impact}

After drop-weight impact tests, the failure patterns of part of the specimens with and without CFs are shown in Figure 6. As expected, for all the specimens without CFs, when the first visible crack appears, the specimens suddenly broke down into two pieces and showed an obviously brittle failure behavior. For the specimens with CFs at a low level, its failure pattern is similar to the specimens without $\mathrm{CFs}$, but some specimens broke down into three pieces (Figure 6b). For the specimens with CFs at a high level, after the first visible crack appears, the specimen can continue to bear the impact loads, and finally break into two or three or four pieces (Figure $6 c, d$ ). It is worth noting that no matter whether the dosage of CFs is high or low, the specimens will eventually be wholly separated into several parts, which is similar to the basalt fibers reinforced concrete [45] but different from the impact 
failure phenomenon - the specimen still remains intact—of steel fibers reinforced concrete, macro polypropylene fibers reinforced concrete, NiTi-SMA fibers reinforced concrete, and polypropylene fibers reinforced concrete $[21,36,46]$. The reason is that the diameter of CFs is only $7.3 \mu \mathrm{m}$, and the elongation at the break of $\mathrm{CFs}$ is no greater than $2.05 \%$; when $\mathrm{CFs}$ are added into coral concrete, there are tens of millions of micro CFs that exist in the coral concrete matrix, and almost all the microcracks have micro $\mathrm{CFs}$, which can restrain the microcracks propagation and hence enhance the impact performance of CFRCC at the microcrack stage, but many CFs have been broken or pulled out at macrocracks stage, so the CFs mainly act in the microcrack stage, and have less hindrance effect on large cracks. Moreover, with the strength grade and CF dosage increasing, a more profound impact pit and more debris were observed at the central surface of the specimen when the specimen fails.

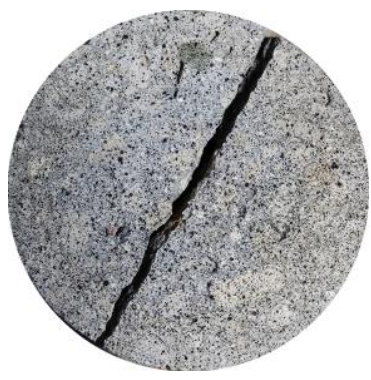

(a)

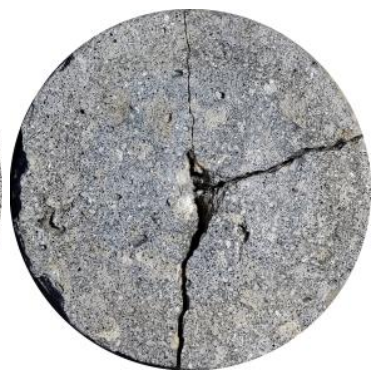

(b)

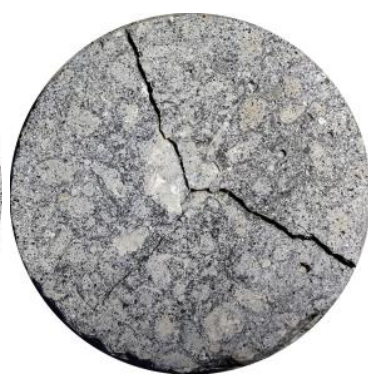

(c)

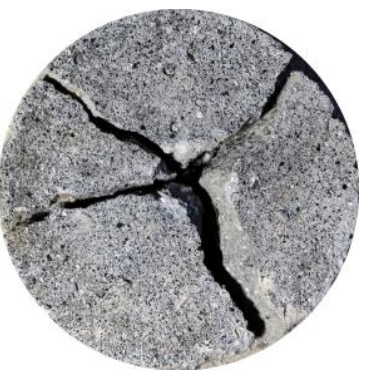

(d)

Figure 6. The failure patterns of part of specimens: (a) CC30C00; (b) CC30C06; (c) CC30C15; (d) CC20C20.

Figure 7 shows the fracture surface of part of the specimens after repeated drop-weight impact tests. It can be seen that, when the concrete strength grade is C20, there is a small amount of coral coarse aggregates broken (see Figure 7a), but almost all coral coarse aggregates broke (see Figure 7c) when the concrete strength grade is raised to C40. It can be concluded that the fracture rate of coral aggregates on the fracture surface increases with the increase of concrete strength grade. This phenomenon can be attributed to the relatively low strength of the coral coarse aggregates and the excellent bonding properties between the coral coarse aggregates and the cement matrix due to the rough surface morphology of the coral coarse aggregates [47].

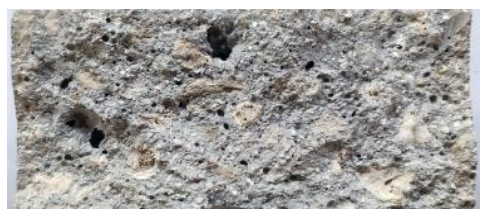

(a)

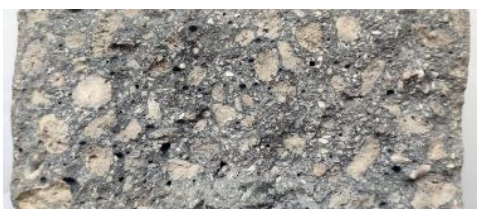

(b)

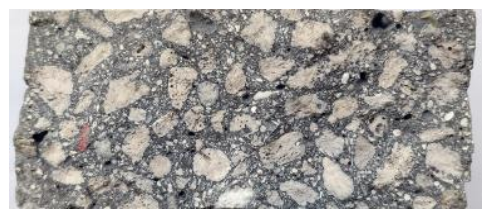

(c)

Figure 7. The fracture surface of part of specimens: (a) C20; (b) C30; (c) C40.

\subsection{Effect of CFs on the Impact Resistance}

Table 5 summarizes the drop-weight impact test results for all the CFRCC mixtures (the detailed results of each specimen see Appendix A Table A1) where an increase in the number of post-first crack blow $(I N P B)$ is introduced, and the INPB is calculated as follows:

$$
I N P B=N_{2}-N_{1}
$$

where $N_{1}$ and $N_{2}$ are representing the number of blows at initial crack and final failure, respectively. 
Table 5. The drop-weight impact tests results.

\begin{tabular}{|c|c|c|c|c|c|c|c|c|c|c|c|}
\hline \multirow[t]{2}{*}{ No. } & \multicolumn{3}{|c|}{$\begin{array}{c}\text { Average Number } \\
\text { of Blows }\end{array}$} & \multicolumn{3}{|c|}{ Standard Deviation } & \multicolumn{3}{|c|}{ Coefficient of Variation } & \multirow[t]{2}{*}{$W_{1}(\mathrm{~J})$} & \multirow[t]{2}{*}{$W_{2}(\mathrm{~J})$} \\
\hline & $N_{1}$ & $\mathrm{~N}_{2}$ & $I N P B$ & $\sigma_{N_{1}}$ & $\sigma_{N_{2}}$ & $\sigma_{I N P B}$ & $C V_{N_{1}}$ & $C V_{\mathrm{N}_{2}}$ & $C V_{I N P B}$ & & \\
\hline CC20C00 & 13.0 & 13.0 & 0.0 & 2.14 & 2.14 & 0.00 & 0.16 & 0.16 & 0.00 & 287 & 287 \\
\hline СС20С03 & 14.0 & 14.5 & 0.5 & 2.07 & 2.33 & 0.79 & 0.15 & 0.16 & 1.59 & 309 & 320 \\
\hline CC20C06 & 16.0 & 16.8 & 0.8 & 2.20 & 2.19 & 0.45 & 0.14 & 0.13 & 0.60 & 353 & 371 \\
\hline CC20C10 & 18.1 & 19.4 & 1.3 & 2.90 & 2.77 & 0.34 & 0.16 & 0.14 & 0.27 & 400 & 428 \\
\hline CC20C15 & 20.9 & 23.1 & 2.3 & 4.85 & 5.41 & 1.26 & 0.23 & 0.23 & 0.56 & 461 & 510 \\
\hline CC20C20 & 24.0 & 27.3 & 3.3 & 3.85 & 3.99 & 0.84 & 0.16 & 0.15 & 0.26 & 530 & 603 \\
\hline CС $30 С 00$ & 26.9 & 27.0 & 0.1 & 2.95 & 2.88 & 0.28 & 0.11 & 0.11 & 2.26 & 594 & 596 \\
\hline СС30С03 & 29.0 & 29.6 & 0.6 & 6.37 & 6.39 & 0.77 & 0.22 & 0.22 & 1.22 & 640 & 653 \\
\hline СС30С06 & 34.0 & 34.6 & 0.6 & 7.17 & 7.46 & 0.81 & 0.21 & 0.22 & 1.29 & 750 & 764 \\
\hline СС30С10 & 39.1 & 41.1 & 2.0 & 3.68 & 3.56 & 0.95 & 0.09 & 0.09 & 0.48 & 863 & 907 \\
\hline СС30С15 & 46.0 & 49.0 & 3.0 & 8.23 & 8.18 & 0.70 & 0.18 & 0.17 & 0.23 & 1015 & 1082 \\
\hline СС $30 \mathrm{C} 20$ & 52.9 & 57.6 & 4.8 & 11.26 & 11.71 & 2.58 & 0.21 & 0.20 & 0.54 & 1168 & 1271 \\
\hline СС40C00 & 39.0 & 39.3 & 0.3 & 6.21 & 6.11 & 0.36 & 0.16 & 0.16 & 1.46 & 861 & 867 \\
\hline СС40C03 & 41.9 & 42.4 & 0.5 & 9.20 & 8.93 & 0.48 & 0.22 & 0.21 & 0.96 & 925 & 936 \\
\hline СС40C06 & 49.0 & 50.1 & 1.1 & 9.99 & 10.47 & 1.12 & 0.20 & 0.21 & 1.00 & 1082 & 1106 \\
\hline CC40C10 & 57.9 & 60.0 & 2.1 & 7.43 & 7.17 & 1.09 & 0.13 & 0.12 & 0.51 & 1278 & 1324 \\
\hline CC40C15 & 69.0 & 72.9 & 3.9 & 8.94 & 9.08 & 1.26 & 0.13 & 0.12 & 0.33 & 1523 & 1609 \\
\hline CC40C20 & 81.9 & 88.0 & 6.1 & 13.88 & 14.59 & 1.83 & 0.17 & 0.17 & 0.30 & 1808 & 1942 \\
\hline
\end{tabular}

For the specimens of $\mathrm{CC} 20 \mathrm{C} 00$, the first crack impact energy $\left(W_{1}\right)$ equals the failure impact energy $\left(W_{2}\right)$. For the specimens of CC30C00 and CC40C00, the failure impact energy $\left(W_{2}\right)$ is only $2 \mathrm{~J}$ and $6 \mathrm{~J}$ more than the first crack impact energy $\left(W_{1}\right)$. That is to say, when the first visible crack appears, the final failure of the specimen will occur at the same time, and the specimens without CFs show distinct brittle behavior.

Figure 8 shows the effect of CFs dosage on the impact energy at first crack $\left(W_{1}\right)$ and final failure $\left(W_{2}\right)$ of CFRCC of three strength grades. It is easily found from the Figure 8 that adding CFs in coral concrete can improve the first impact energy and the final failure impact energy, and further improvement was recorded for the final failure impact energy, as compared to the first impact energy. With the increasing of additional CFs in coral concrete, the increase percentage of $W_{1}$ and $W_{2}$ is also increasing. In other words, the addition of CFs in coral concrete can improve both the initial crack and ultimate failure impact resistances of CFRCC, and its improvement increases with the increase of CF dosage.

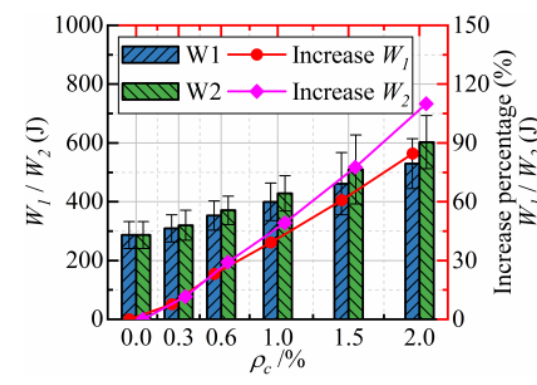

(a)

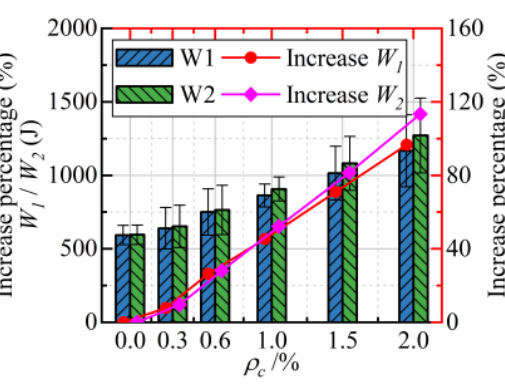

(b)

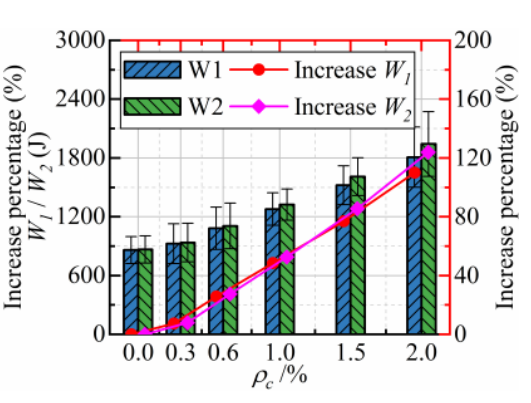

(c)

Figure 8. The impact energy at first crack and final failure of specimens with different CFs: (a) C20; (b) C30; (c) C40.

Figure 9 exhibits the effect of CFs dosage on the INPB and $I N P B / N_{1}$ of three strength grades' CFRCC. In Figure 9, there is a clear trend of INPB and INPB/N $N_{1}$ increasing with the increasing of CFs dosage. With the increasing of concrete strength grade, the INPB is also increasing while the INPB/ $N_{1}$ decreases. It must be noted that, even with a CF dosage of $2.0 \%$, INPB is also small, only $3.3,4.8$, 
and 6.1 for $\mathrm{C} 20, \mathrm{C} 30$, and $\mathrm{C} 40$, respectively, and the $I N P B / N_{1}$ for all the mixture is no more than $14 \%$. Mastali et al. [27] conducted the drop-weight impact test on CF reinforced self-compacting concrete and obtained similar results. That is to say, the improvement effect of CFs on the impact resistance of specimens after cracking is not apparent, which is obviously different from the test results of steel fibers reinforced concrete and macro PP fibers reinforced concrete obtained by Zhang, Rahmani, Ding, and Murali et al. [36,48-50]. The explanation for this is that the steel fibers are macro fibers (the diameter is generally higher than $0.4 \mathrm{~mm}$ ) and have a relatively large elongation at break (more than $3.5 \%$ ), so the steel fibers can play an excellent bridging role in macrocracks after the first visible crack appeared of specimens. However, the CFs have a diameter of only $7.3 \mu \mathrm{m}$ and an elongation at break of only $2.05 \%$, so the CFs mainly play a positive role in microcracks and a less positive role in macrocracks under the drop-weight impact test. The previous research data $[26,50,51]$ also clearly indicated that, in the drop-weight impact test, the larger the diameter of fiber and elongation at break is, the larger the INPB will be, when other conditions are the same.

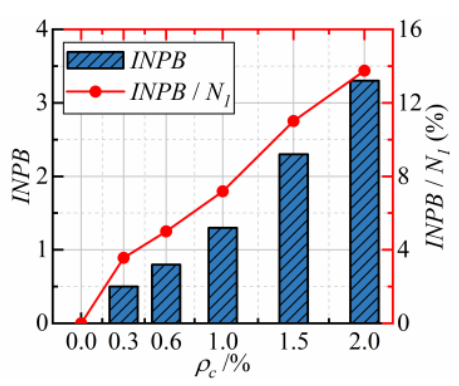

(a)

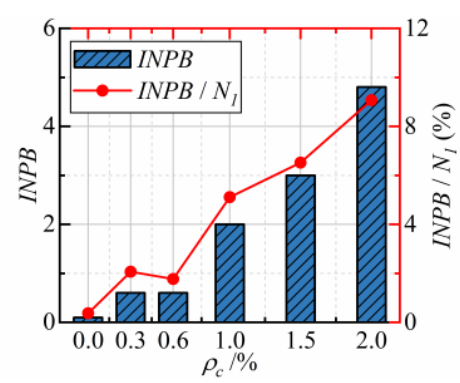

(b)

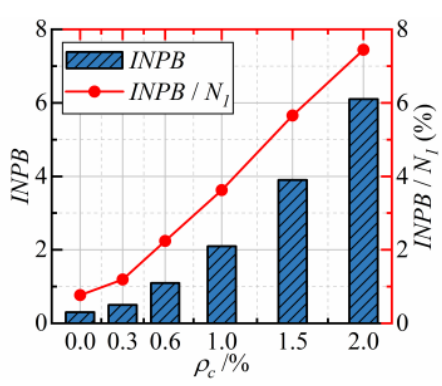

(c)

Figure 9. The INPB of specimens with different CFs: (a) C20; (b) C30; (c) C40.

\subsection{Effect of Concrete Strength Grade on the Impact Resistance}

As shown in Figure 10, the impact energy at first crack $\left(W_{1}\right)$ and final failure $\left(W_{2}\right)$ and strength grade is approximately in a linear relationship, which indicates that, for CFRCC, the higher the concrete strength grade is, the higher the impact resistance will be. For polypropylene fibers reinforced coral concrete, Wang et al. [21] also reached a similar conclusion.

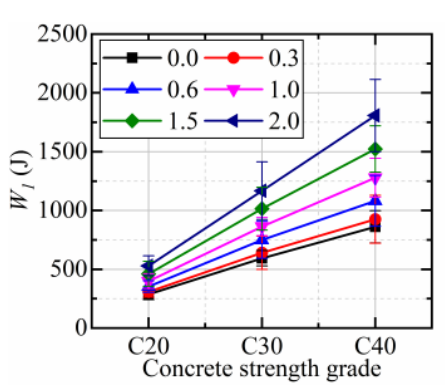

(a)

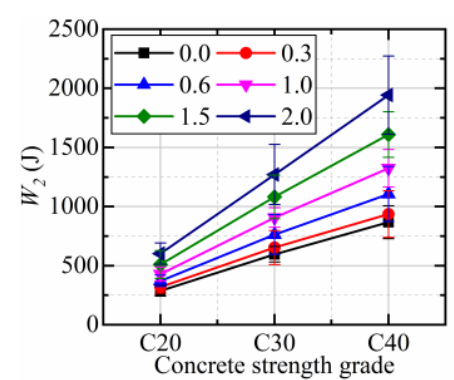

(b)

Figure 10. Comparison of test value and predicted value of splitting tensile strength: (a) $W_{1}$; (b) $W_{2}$.

\subsection{Correlation between Cube Compressive Strength, CFs Dosage, and Impact Energy}

After regression analysis, it is found that the effect of $\mathrm{CFs}$ dosage and cube compressive strength on the impact resistance of CFRCC can be illustrated by Equation (3):

$$
W_{1}\left(W_{2}\right)=\left(a+b f_{c u}^{1.5}\right)\left(c+d \rho_{c}^{1.2}\right),
$$

where $W_{1}$ and $W_{2}$ are the impact energy at the first visible crack and final failure, respectively $(\mathrm{J}) ; f_{c u}$ is the cube compressive strength (MPa); $\rho_{c}$ is the CFs dosage (\%); $a, b, c$, and $d$ are fitting parameters. 
The fitting results of Equation (3) to test data are presented in Table 6, Figure 11, and Figure 12. It can be seen that the standardized residuals of most of the points are in the range of -2 to 2 , and the Adjusted $R^{2}$ are 0.995 and 0.996 for $W_{1}$ and $W_{2}$, respectively, which indicates that Equation (3) fits the experimental data well. Moreover, Figures $11 \mathrm{c}$ and $12 \mathrm{c}$ also indicate that the fitting values are very close to the experimental values.

Table 6. Fitting results.

\begin{tabular}{cccccc}
\hline $\begin{array}{c}\text { Dependent } \\
\text { Variable }\end{array}$ & a & b & c & d & Adjusted R $^{\mathbf{2}}$ \\
\hline$W_{1}$ & -32.035 & 1.306 & 2.601 & 0.848 & 0.995 \\
$W_{2}$ & -26.791 & 1.326 & 2.510 & 0.975 & 0.996 \\
\hline
\end{tabular}

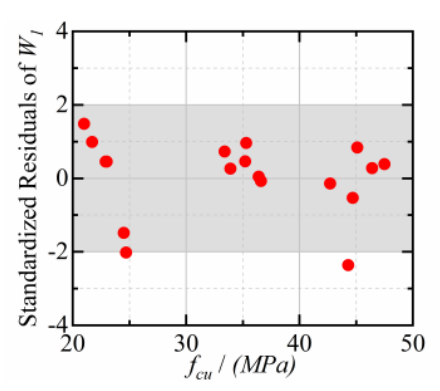

(a)

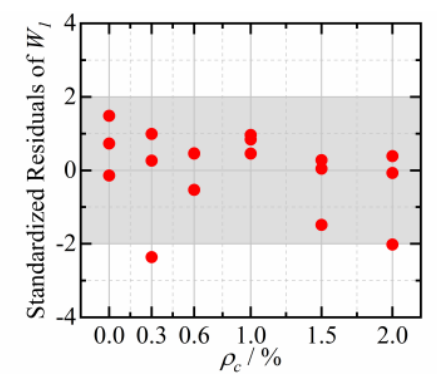

(b)

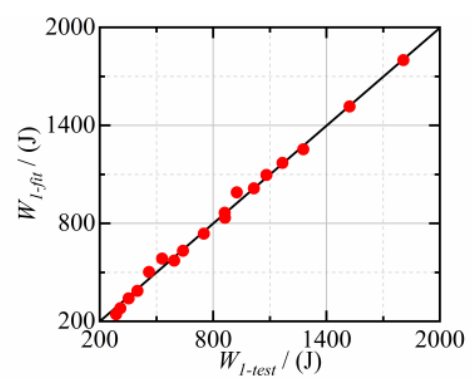

(c)

Figure 11. The fitting results of $W_{1}$ : (a) Standardized Residuals vs. $f_{c u}$; (b) Standardized Residuals vs. $\rho_{c} ;(\mathbf{c})$ comparison of test and fitting.

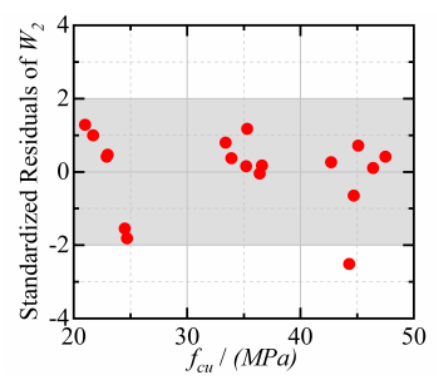

(a)

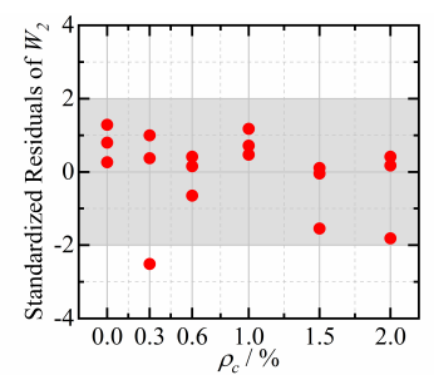

(b)

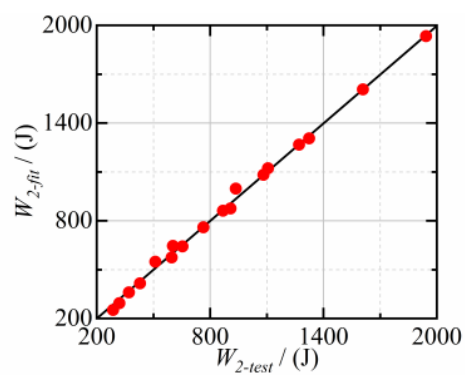

(c)

Figure 12. The fitting results of $W_{2}$ : (a) Standardized Residuals vs. $f_{c u}$; (b) Standardized Residuals vs. $\rho_{c} ;(\mathbf{c})$ comparison of test and fitting.

\section{Distribution of Impact Resistance Factors}

Over the past few decades, several statistical models have been employed for analysis of the variations in impact test results of concrete [36,46,49,50,52-56]. Among them, the normal distribution model is widely used. However, many researchers $[54,56]$ pointed out that the impact test results exhibited poor fitness with normal distribution at a $95 \%$ confidence level. By contrast, the two-parameter Weibull distribution has been proved by some researchers $[36,46,50]$ that it is appropriate to evaluate the impact performance of concrete under impact. Therefore, for analyzing the variations in the impact resistance of CFRCC under drop-weight impact test, the two-parameter Weibull distribution is employed in this study.

According to [46], the expression of the cumulative distribution function $F(x)$ of two-parameter Weibull probability law is as follows:

$$
F(x)=1-\exp \left[-\left(\frac{x-x_{0}}{\lambda}\right)^{k}\right]
$$


where $x$ is the impact life of the concrete; $\mathrm{k}$ is the shape parameter; $\lambda$ is the scale parameter; $\mathrm{x} 0$ is the minimum impact life of concrete and assumed to be 0 in this study.

The function $F(x)$ denotes the failure probability of concrete under impact loading. Thus, the probability estimator $L(x)$ may be defined as:

$$
L(x)=1-F(x)=\exp \left[-\left(\frac{x-x_{0}}{\lambda}\right)^{k}\right]
$$

Take $x_{0}=0$ and the natural logarithm twice on both sides of Equation (5) to get:

$$
\ln \ln \frac{1}{L(x)}=k \ln x-k \ln \lambda .
$$

Thus, Equation (6) can be used to verify whether the impact resistance factors $\left(N_{1}\right.$, and $\left.N_{2}\right)$ of CFRCC follow the two-parameter Weibull distribution. Since Equation (6) represents a linear relationship between $\ln \ln (1 / L(x))$ and $\ln x$, if an appropriately linear relationship between $\ln \ln (1 / L(x))$ and $\ln x$ is observed from the test results, the conclusion that using two-parameter Weibull distribution to characterize the statistical distribution of impact test results of CFRCC is feasible can be conducted. In order to verify whether there is an appropriately linear relationship between $\ln (1 / L(x))$ and $\ln x$, first, the impact results $\left(N_{1}\right.$, and $\left.N_{2}\right)$ are arranged in an descending order, and then the probability estimator is assumed and the linear regression analysis is performed.

Many probability estimators have been used in previous studies and Murali et al. [50] summarized twenty probability estimators used in previous papers. It can be seen from the summaries of Murali [50] that there are two expression forms of the probability estimator:

$$
\begin{gathered}
L(x)=\frac{j+\alpha}{n+\beta^{\prime}} \\
L(x)=1-\frac{j+\alpha}{n+\beta},
\end{gathered}
$$

where $j$ is the sequence number of the impact failure specimen; $n$ is the total number of the impact specimens for each mixture; $\alpha$ and $\beta$ are constants.

After trial calculating the test results with Equations (7) and (8), Equation (7) is chosen as the recommended probability estimator in this study, and the values of $\alpha$ and $\beta$ are -0.6 , and 0.9 , respectively. Figure 13 shows the distribution of the impact resistance factor $\left(N_{1}\right.$, and $\left.N_{2}\right)$ of each CFRCC mixture and the corresponding fitted curves, and Table 7 gives the detailed linear regression results. Rahmani et al. [49] pointed out that a $R^{2}$ of 0.7 or higher is sufficient for establishing a reasonable reliability model. Since the appropriately linear relationship plot in Figure 13 and all the impact test results have Adjusted $R^{2}$ equal to or higher than 0.837, the two-parameter Weibull distribution is considered suitable for establishing the statistical distribution of impact test data of coral concrete incorporating CFs. These developed reliability curves are highly suitable as a useful tool to quickly investigate the impact resistance of CFRCC, thereby eliminating the necessity of time-consuming impact testing process. Some previous studies $[36,46,49,50]$ have drawn similar conclusions for other types of fibers reinforced concrete. 


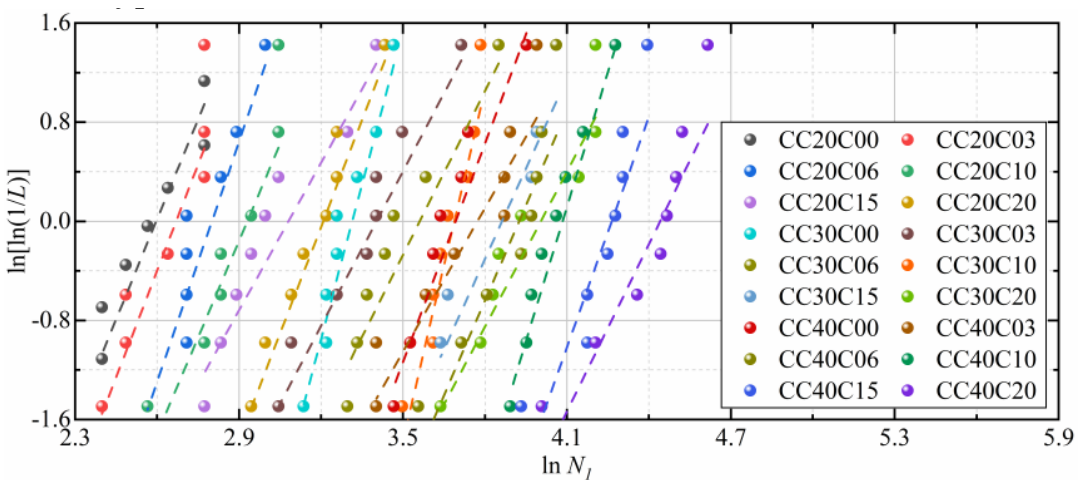

(a)

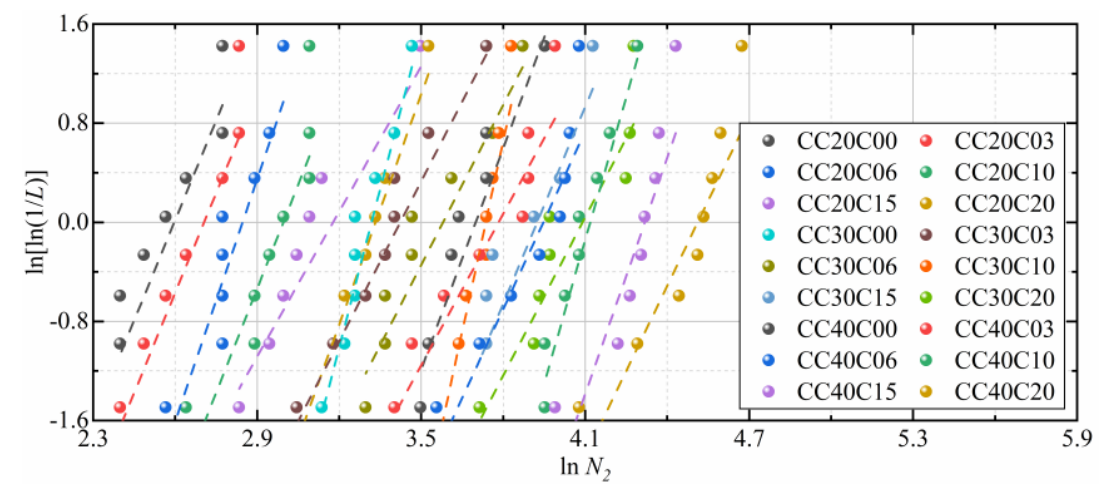

(b)

Figure 13. Linear regression of $N_{1}$ and $N_{2}$ in Weibull distribution: (a) $N_{1}$; (b) $N_{2}$.

Table 7. Linear regression results of impact resistance in Weibull distribution.

\begin{tabular}{|c|c|c|c|c|c|c|}
\hline \multirow{2}{*}{$\begin{array}{l}\text { Specimen } \\
\text { No. }\end{array}$} & \multicolumn{3}{|c|}{$N_{1}$} & \multicolumn{3}{|c|}{$\mathrm{N}_{2}$} \\
\hline & $k$ & $\lambda$ & Adjusted $R^{2}$ & $k$ & $\lambda$ & Adjusted $\mathrm{R}^{2}$ \\
\hline CC20C00 & 5.382 & 13.420 & 0.853 & 5.382 & 13.420 & 0.853 \\
\hline CC20C03 & 5.723 & 14.437 & 0.874 & 5.375 & 14.964 & 0.926 \\
\hline CC20C06 & 6.468 & 16.454 & 0.865 & 6.514 & 17.227 & 0.864 \\
\hline CC20C10 & 5.190 & 18.730 & 0.884 & 5.593 & 20.001 & 0.841 \\
\hline CC20C15 & 3.971 & 21.779 & 0.881 & 3.910 & 23.983 & 0.894 \\
\hline CC20C20 & 5.736 & 24.720 & 0.962 & 6.196 & 28.027 & 0.982 \\
\hline СС $30 \mathrm{C} 00$ & 8.318 & 27.497 & 0.924 & 8.507 & 27.615 & 0.919 \\
\hline СС30С03 & 4.173 & 30.040 & 0.946 & 4.302 & 30.667 & 0.950 \\
\hline СС30C06 & 4.410 & 35.203 & 0.888 & 4.298 & 35.869 & 0.885 \\
\hline CС30C10 & 9.444 & 39.945 & 0.940 & 10.241 & 41.929 & 0.956 \\
\hline CС30C15 & 4.874 & 47.590 & 0.849 & 5.302 & 50.598 & 0.858 \\
\hline CC30C20 & 4.179 & 54.810 & 0.912 & 4.259 & 59.766 & 0.869 \\
\hline CC40C00 & 5.878 & 40.164 & 0.895 & 5.954 & 40.420 & 0.871 \\
\hline СС40C03 & 3.862 & 43.493 & 0.908 & 4.071 & 43.957 & 0.927 \\
\hline CC40C06 & 5.112 & 50.648 & 0.902 & 4.783 & 51.757 & 0.897 \\
\hline CC40C10 & 7.251 & 59.354 & 0.942 & 7.689 & 61.472 & 0.938 \\
\hline CC40C15 & 6.201 & 71.067 & 0.848 & 6.363 & 75.026 & 0.837 \\
\hline CC40C20 & 4.503 & 84.860 & 0.902 & 4.579 & 91.076 & 0.885 \\
\hline
\end{tabular}

According to Equations (5) and (6), the number of blows $\left(N_{1}, N_{2}\right)$ of CFRCC at the corresponding failure probability $P$ can be derived as follows:

$$
N=x=\frac{1}{k} \ln \ln \frac{1}{1-P}+\ln \lambda,
$$

where $P$ is the failure probability. 
Figure 14 shows the $N_{2}$ of CFRCC acquired by reliability analysis at different failure probability. It is easy to note that the impact resistance performance of CFRCC increases approximately linearly with the $\mathrm{CF}$ dosage increasing at the same failure probability.

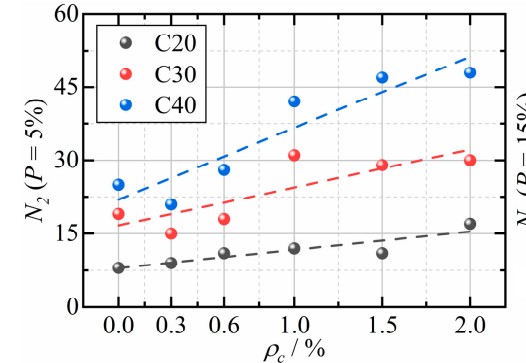

(a)

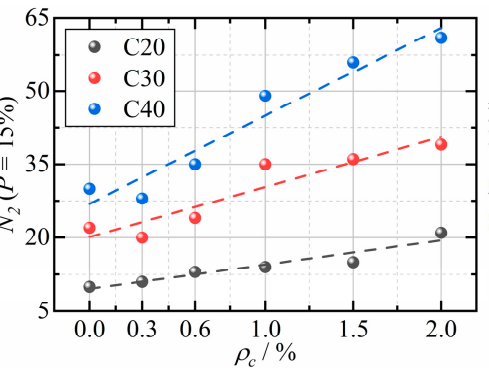

(b)

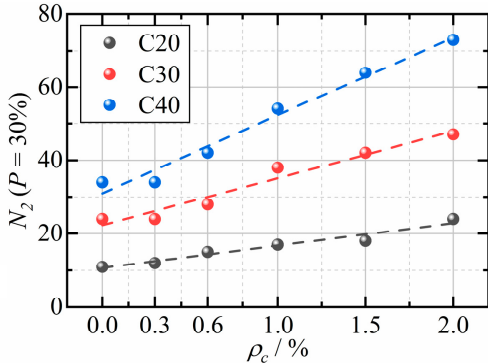

(c)

Figure 14. $N_{2}$ vs. $\rho_{c}$ based on reliability analysis with different failure probability: (a) $P=5 \%$; (b) $P=$ $15 \%$; (c) $P=30 \%$.

As an example of verifying whether the two-parameter Weibull distribution recommended in this study is also suitable to evaluate the impact performance of other fibers reinforced concrete, the test results of Ding et al. [36] for macro polypropylene fibers and steel fibers reinforced concrete are also analyzed by using Equations (6) and (7), and the regression analysis results are given in Table 8. From Table 8 , it can be seen that the Adjusted $\mathrm{R}^{2}$ of each mixture is no less than 0.833 , which indicates that the two-parameter Weibull distribution recommended in this study is also suitable to evaluate the impact performance of other types of fibers reinforced concrete.

Table 8. Linear regression results of impact resistance of Ding et al.'s [36] results in Weibull distribution.

\begin{tabular}{ccccccc}
\hline \multirow{2}{*}{$\begin{array}{c}\text { Specimen } \\
\text { No. }\end{array}$} & \multicolumn{3}{c}{$\boldsymbol{N}_{\mathbf{1}}$} & \multicolumn{3}{c}{$\boldsymbol{N}_{\mathbf{2}}$} \\
\cline { 2 - 7 } & $\boldsymbol{k}$ & $\boldsymbol{\lambda}$ & Adjusted $\mathbf{R}^{\mathbf{2}}$ & $\boldsymbol{\lambda}$ & $\boldsymbol{k}$ & ${\text { Adjusted } \mathbf{R}^{\mathbf{2}}}$ \\
\cline { 2 - 7 } NC & 1.243 & 11.674 & 0.927 & 1.243 & 11.674 & 0.927 \\
PP4 & 2.187 & 15.109 & 0.712 & 2.726 & 30.833 & 0.865 \\
PP6 & 6.892 & 21.914 & 0.958 & 5.357 & 38.456 & 0.952 \\
SF20 & 1.134 & 22.016 & 0.943 & 1.352 & 41.712 & 0.958 \\
SF35 & 0.860 & 19.937 & 0.988 & 1.389 & 45.208 & 0.899 \\
\hline
\end{tabular}

\section{Conclusions}

In this study, the impact resistance of CFRCC under impact loading was investigated by conducting the drop-weight impact test. Based on the experimental results and regression analysis, the main conclusions can be drawn as follows:

(1) The addition of CFs into coral concrete changed the failure pattern of coral concrete specimens under impact loading from obvious brittleness to relatively good ductility.

(2) CF addition can improve the impact resistance at initial crack and final failure of coral concrete. Still, the improvement of the impact resistance after initial cracking due to the addition of CFs is not as significant as steel fibers.

(3) The impact resistance of CFRCC increases with the increase of CF dosage and concrete strength grade.

(4) The impact energy ( $W_{1}$, and $\left.W_{2}\right)$ of CFRCC can be evaluated by the cube compressive strength and CFs dosage using Equation (3).

(5) The two-parameter Weibull distribution theory is proved capable of adequately representing the impact test results, and these developed reliability curves through the two-parameter Weibull 
distribution theory can be considered a useful tool to investigate the impact resistance of CFRCC quickly.

Author Contributions: B.L. and Z.D. designed the research; B.L., J.Z., X.W., J.G., and X.Z. performed the research; B.L. analyzed the data and wrote the paper; Z.D. and H.W. performed review and editing. All authors read and approved the final manuscript.

Funding: This research was funded by the National Natural Science Foundation of China, Grant Nos. 51868005, 51478126; the Guangxi Natural Science Foundation Program, Grant No. 2018GXNSFAA050133; the "College Students Innovation and Entrepreneurship Training Program" of Guangxi University, Grant No. 201910593161, the Innovation Project of Guangxi Graduate Education.

Conflicts of Interest: The authors declare no conflict of interest.

\section{Appendix A}

Table A1. The detail drop-weight impact test results of each specimen.

\begin{tabular}{|c|c|c|c|c|c|c|c|c|c|c|c|c|}
\hline No. & & 1 & 2 & 3 & 4 & 5 & 6 & 7 & 8 & Mean & $\begin{array}{l}\text { Standard } \\
\text { Deviation }\end{array}$ & $\begin{array}{l}\text { Coefficient } \\
\text { of Variation }\end{array}$ \\
\hline \multirow{3}{*}{ СС20С00 } & $N_{1}$ & 11 & 12 & 16 & 11 & 16 & 14 & 11 & 13 & 13.0 & 2.14 & 0.16 \\
\hline & $\mathrm{N}_{2}$ & 11 & 12 & 16 & 11 & 16 & 14 & 11 & 13 & 13.0 & 2.14 & 0.16 \\
\hline & $I N P B$ & 0 & 0 & 0 & 0 & 0 & 0 & 0 & 0 & 0.0 & 0.00 & 0.00 \\
\hline \multirow{3}{*}{ СС20C03 } & $N_{1}$ & 16 & 11 & 16 & 16 & 12 & 12 & 14 & 15 & 14.0 & 2.07 & 0.15 \\
\hline & $\mathrm{N}_{2}$ & 16 & 11 & 17 & 17 & 12 & 13 & 14 & 16 & 14.5 & 2.33 & 0.16 \\
\hline & $I N P B$ & 0 & 0 & 1 & 1 & 0 & 1 & 0 & 1 & 0.5 & 0.79 & 1.59 \\
\hline \multirow{3}{*}{ CC20C06 } & $N_{1}$ & 13 & 17 & 15 & 20 & 15 & 15 & 15 & 18 & 16.0 & 2.20 & 0.14 \\
\hline & $N_{2}$ & 13 & 18 & 16 & 20 & 16 & 16 & 16 & 19 & 16.8 & 2.19 & 0.13 \\
\hline & $I N P B$ & 0 & 1 & 1 & 0 & 1 & 1 & 1 & 1 & 0.8 & 0.45 & 0.60 \\
\hline \multirow{3}{*}{ CC20C10 } & $N_{1}$ & 13 & 17 & 17 & 19 & 21 & 21 & 21 & 16 & 18.1 & 2.90 & 0.16 \\
\hline & $\mathrm{N}_{2}$ & 14 & 19 & 18 & 20 & 22 & 22 & 22 & 18 & 19.4 & 2.77 & 0.14 \\
\hline & $I N P B$ & 1 & 2 & 1 & 1 & 1 & 1 & 1 & 2 & 1.3 & 0.34 & 0.27 \\
\hline \multirow{3}{*}{ CC20C15 } & $N_{1}$ & 18 & 18 & 18 & 19 & 17 & 27 & 30 & 20 & 20.9 & 4.85 & 0.23 \\
\hline & $\mathrm{N}_{2}$ & 20 & 20 & 20 & 21 & 18 & 30 & 33 & 23 & 23.1 & 5.41 & 0.23 \\
\hline & $I N P B$ & 2 & 2 & 2 & 2 & 1 & 3 & 3 & 3 & 2.3 & 1.26 & 0.56 \\
\hline \multirow{3}{*}{ CС20C20 } & $N_{1}$ & 22 & 26 & 19 & 25 & 20 & 23 & 26 & 31 & 24.0 & 3.85 & 0.16 \\
\hline & $N_{2}$ & 25 & 29 & 21 & 28 & 24 & 27 & 30 & 34 & 27.3 & 3.99 & 0.15 \\
\hline & $I N P B$ & 3 & 3 & 2 & 3 & 4 & 4 & 4 & 3 & 3.3 & 0.84 & 0.26 \\
\hline \multirow{3}{*}{ СС $30 \mathrm{C} 00$} & $N_{1}$ & 32 & 28 & 30 & 25 & 25 & 23 & 26 & 26 & 26.9 & 2.95 & 0.11 \\
\hline & $\mathrm{N}_{2}$ & 32 & 28 & 30 & 25 & 26 & 23 & 26 & 26 & 27.0 & 2.88 & 0.11 \\
\hline & $I N P B$ & 0 & 0 & 0 & 0 & 1 & 0 & 0 & 0 & 0.1 & 0.28 & 2.26 \\
\hline \multirow{3}{*}{ СС30С03 } & $N_{1}$ & 33 & 29 & 26 & 22 & 30 & 30 & 41 & 21 & 29.0 & 6.37 & 0.22 \\
\hline & $\mathrm{N}_{2}$ & 34 & 29 & 27 & 24 & 30 & 30 & 42 & 21 & 29.6 & 6.39 & 0.22 \\
\hline & $I N P B$ & 1 & 0 & 1 & 2 & 0 & 0 & 1 & 0 & 0.6 & 0.77 & 1.22 \\
\hline \multirow{3}{*}{ СС30С06 } & $N_{1}$ & 28 & 42 & 32 & 36 & 29 & 27 & 31 & 47 & 34.0 & 7.17 & 0.21 \\
\hline & $\mathrm{N}_{2}$ & 29 & 43 & 32 & 37 & 29 & 27 & 32 & 48 & 34.6 & 7.46 & 0.22 \\
\hline & $I N P B$ & 1 & 1 & 0 & 1 & 0 & 0 & 1 & 1 & 0.6 & 0.81 & 1.29 \\
\hline \multirow{3}{*}{ СС $30 \mathrm{C} 10$} & $N_{1}$ & 33 & 42 & 37 & 44 & 43 & 38 & 37 & 39 & 39.1 & 3.68 & 0.09 \\
\hline & $\mathrm{N}_{2}$ & 35 & 43 & 38 & 46 & 44 & 42 & 39 & 42 & 41.1 & 3.56 & 0.09 \\
\hline & $I N P B$ & 2 & 1 & 1 & 2 & 1 & 4 & 2 & 3 & 2.0 & 0.95 & 0.48 \\
\hline \multirow{3}{*}{ СС30С15 } & $N_{1}$ & 39 & 38 & 38 & 58 & 54 & 40 & 53 & 48 & 46.0 & 8.23 & 0.18 \\
\hline & $\mathrm{N}_{2}$ & 42 & 41 & 42 & 62 & 57 & 43 & 55 & 50 & 49.0 & 8.18 & 0.17 \\
\hline & $I N P B$ & 3 & 3 & 4 & 4 & 3 & 3 & 2 & 2 & 3.0 & 0.70 & 0.23 \\
\hline \multirow{3}{*}{ СС $30 \mathrm{C} 20$} & $N_{1}$ & 51 & 44 & 38 & 67 & 46 & 63 & 67 & 47 & 52.9 & 11.26 & 0.21 \\
\hline & $\mathrm{N}_{2}$ & 53 & 51 & 41 & 72 & 50 & 71 & 70 & 53 & 57.6 & 11.71 & 0.20 \\
\hline & $I N P B$ & 2 & 7 & 3 & 5 & 4 & 8 & 3 & 6 & 4.8 & 2.58 & 0.54 \\
\hline \multirow{3}{*}{ СС40C00 } & $N_{1}$ & 36 & 38 & 32 & 42 & 52 & 41 & 34 & 37 & 39.0 & 6.21 & 0.16 \\
\hline & $\mathrm{N}_{2}$ & 36 & 38 & 33 & 42 & 52 & 42 & 34 & 37 & 39.3 & 6.11 & 0.16 \\
\hline & INPB & 0 & 0 & 1 & 0 & 0 & 1 & 0 & 0 & 0.3 & 0.36 & 1.46 \\
\hline
\end{tabular}


Table A1. Cont.

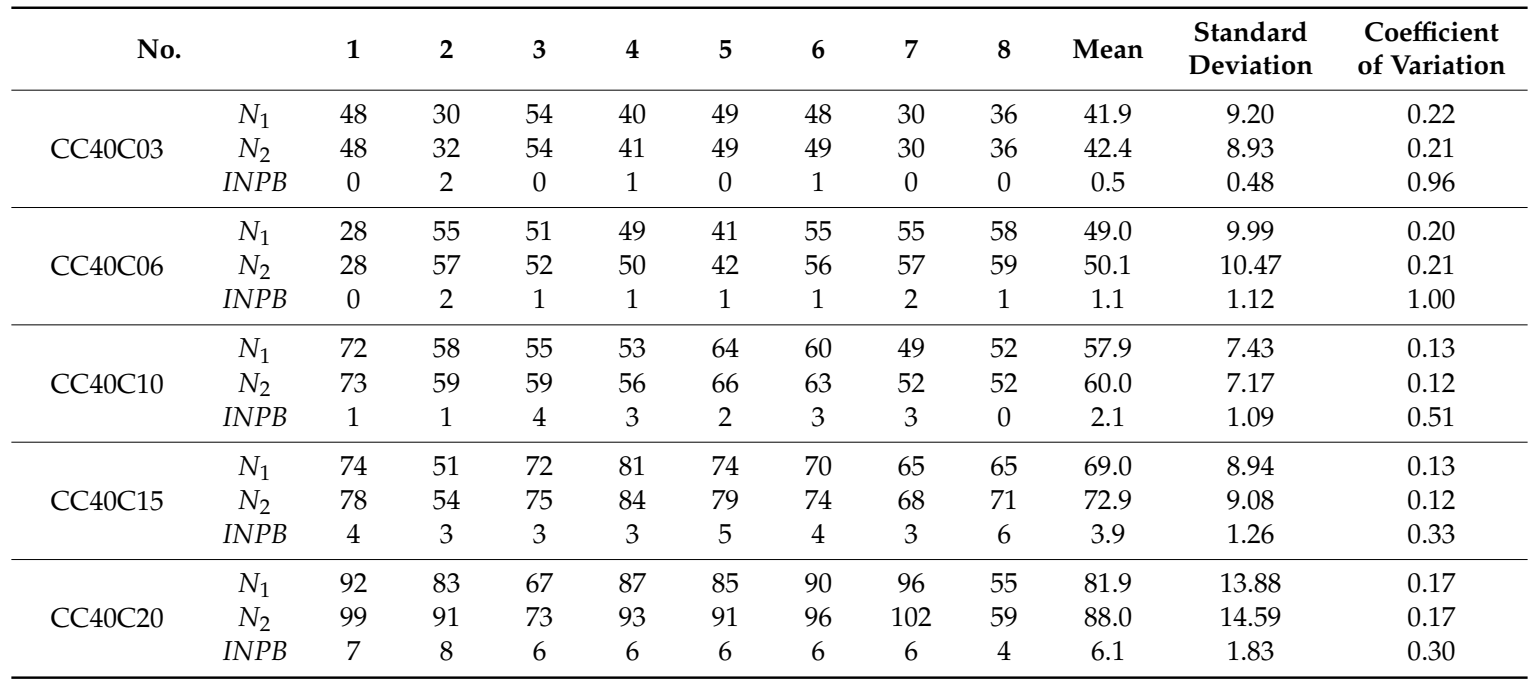

\section{References}

1. Lyu, B.; Wang, A.; Zhang, Z.; Liu, K.; Xu, H.; Shi, L.; Sun, D. Coral aggregate concrete: Numerical description of physical, chemical and morphological properties of coral aggregate. Cem. Concr. Compos. 2019, 100, 25-34. [CrossRef]

2. Yang, S.; Yang, C.; Huang, M.; Liu, Y.; Jiang, J.; Fan, G. Study on bond performance between frp bars and seawater coral aggregate concrete. Constr. Build. Mater. 2018, 173, 272-288. [CrossRef]

3. Wang, Q.; Li, P.; Tian, Y.; Chen, W.; Su, C. Mechanical properties and microstructure of portland cement concrete prepared with coral reef sand. J. Wuhan Univ. Technol. Mat. Sci. Ed. 2016, 31, 996-1001. [CrossRef]

4. Ma, L.; Li, Z.; Liu, J.; Duan, L.; Wu, J. Mechanical properties of coral concrete subjected to uniaxial dynamic compression. Constr. Build. Mater. 2019, 199, 244-255. [CrossRef]

5. Wang, Y.; Zhang, S.; Niu, D.; Su, L.; Luo, D. Effects of silica fume and blast furnace slag on the mechanical properties and chloride ion distribution of coral aggregate concrete. Constr. Build. Mater. 2019, 214, 648-658. [CrossRef]

6. Ehlert, R. Coral Concrete at Bikini Atoll. Concr. Int. 1991, 13, 19-24.

7. Tang, J.; Cheng, H.; Zhang, Q.; Chen, W.; Li, Q. Development of properties and microstructure of concrete with coral reef sand under sulphate attack and drying-wetting cycles. Constr. Build. Mater. 2018, 165, 647-654. [CrossRef]

8. Wang, Y.; Shui, Z.; Gao, X.; Huang, Y.; Yu, R.; Li, X.; Yang, R. Utilizing coral waste and metakaolin to produce eco-friendly marine mortar: Hydration, mechanical properties and durability. J. Clean. Prod. 2019, 219, 763-774. [CrossRef]

9. Liu, J.; Ou, Z.; Peng, W.; Guo, T.; Deng, W.; Chen, Y. Literature review of coral concrete. Arab. J. Sci. Eng. 2018, 43, 1529-1541. [CrossRef]

10. Howdyshell, P.A. The Use of Coral as an Aggregate for Portland Cement Concrete Structures; No. CERL-TR-M-88; Construction Engineering Research Lab (Army): Champaign, IL, USA, June 1974.

11. Dempsey, G. Coral and salt water as concrete materials. J. Proc. 1951, 48, 157-166.

12. Da, B.; Yu, H.; Ma, H.; Tan, Y.; Mi, R.; Dou, X. Chloride diffusion study of coral concrete in a marine environment. Constr. Build. Mater. 2016, 123, 47-58. [CrossRef]

13. Arumugam, R.A.; Ramamurthy, K. Study of compressive strength characteristics of coral aggregate concrete. Mag. Concr. Res. 1996, 48, 141-148. [CrossRef]

14. Shen, J. Experimental study on compressive strength of coral aggregate concrete mixed with seawater. Soil Eng. Found. 2016, 30, 524-526.

15. Wei, Z.; Li, Z.; Shen, J. Research on the influencing factors of performance of coral concrete and its early mechanical property. Ind. Constr. 2017, 47, 130-136. 
16. Mi, R.J.; Yu, H.F.; Ma, H.Y.; Da, B.; Yuan, Y.F.; Zhang, X.P.; Zhu, H.W.; Dou, X.M. Study on the mechanical property of coral concrete. Ocean Eng. 2016, 34, 47-54.

17. Da, B.; Yu, H.; Ma, H.; Tan, Y.; Mi, R.; Dou, X. Experimental investigation of whole stress-strain curves of coral concrete. Constr. Build. Mater. 2016, 122, 81-89. [CrossRef]

18. Li, Y.; Zhou, L.; Zhang, Y.; Cui, J.; Shao, J. Study on long-term performance of concrete based on seawater, sea sand and coral sand. Adv. Mater. Res. 2013, 706, 512-515. [CrossRef]

19. Lei, W.; Zujing, X.; Cunkeng, L.; Quanlong, L. Mechanical property tests of coral concrete with polypropylene fiber. Concrete 2014, 7, 96-99.

20. Cheng, S.; Shui, Z.; Sun, T.; Yu, R.; Zhang, G. Durability and microstructure of coral sand concrete incorporating supplementary cementitious materials. Constr. Build. Mater. 2018, 171, 44-53. [CrossRef]

21. Gold, E.; Chao, L.; Lei, W. Experimental study on shock resistance of polypropylene fiber reinforced coral concrete. Sci. Technol. Eng. 2019, 19, 244-248.

22. Zhang, M.H.; Li, L.; Paramasivam, P. Flexural toughness and impact resistance of steel-fibre-reinforced lightweight concrete. Mag. Concr. Res. 2004, 56, 251-262. [CrossRef]

23. Agostinacchio, M.; Ciampa, D.; Olita, S. The vibrations induced by surface irregularities in road pavements-A matlab ${ }^{\circledR}$ approach. Eur. Transp. Res. Rev. 2014, 6, 267-275. [CrossRef]

24. Naraganti, S.R.; Pannem, R.M.R.; Putta, J. Impact resistance of hybrid fibre reinforced concrete containing sisal fibres. Ain Shams Eng. J. 2019, 10, 297-305. [CrossRef]

25. Mahakavi, P.; Chithra, R. Impact resistance, microstructures and digital image processing on self-compacting concrete with hooked end and crimped steel fiber. Constr. Build. Mater. 2019, 220, 651-666. [CrossRef]

26. Feng, J.; Sun, W.; Zhai, H.; Wang, L.; Dong, H.; Wu, Q. Experimental study on hybrid effect evaluation of fiber reinforced concrete subjected to drop weight impacts. Materials 2018, 11, 2563. [CrossRef]

27. Mastali, M.; Dalvand, A.; Sattarifard, A. The impact resistance and mechanical properties of the reinforced self-compacting concrete incorporating recycled cfrp fiber with different lengths and dosages. Compos. Part B Eng. 2017, 112, 74-92. [CrossRef]

28. Han, B.; Zhang, L.; Zhang, C.; Wang, Y.; Yu, X.; Ou, J. Reinforcement effect and mechanism of carbon fibers to mechanical and electrically conductive properties of cement-based materials. Constr. Build. Mater. 2016, 125, 479-489. [CrossRef]

29. Rodin, H.I.; Rangelov, M.; Nassiri, S.; Englund, K. Enhancing mechanical properties of pervious concrete using carbon fiber composite reinforcement. J. Mater. Civ. Eng. 2018, 30, 040180123. [CrossRef]

30. Li, M.; Yang, Y.; Liu, M.; Guo, X.; Zhou, S. Hybrid effect of calcium carbonate whisker and carbon fiber on the mechanical properties and microstructure of oil well cement. Constr. Build. Mater. 2015, 93, 995-1002. [CrossRef]

31. Han, B.; Wang, Y.; Dong, S.; Zhang, L.; Ding, S.; Yu, X.; Ou, J. Smart concretes and structures: A review. J. Intell. Mater. Syst. Struct. 2015, 26, 1303-1345. [CrossRef]

32. Bentur, A.; Mindess, S. Fibre Reinforced Cementitious Composites; CRC Press: Boca Raton, FL, USA, 2006.

33. Banyhussan, Q.S.; Yıldırım, G.; Anıl, Ö.; Erdem, R.T.; Ashour, A.; Şahmaran, M. Impact resistance of deflection-hardening fiber reinforced concretes with different mixture parameters. Struct. Concr. 2019, 20, 1036-1050. [CrossRef]

34. Standardization, C.A.F.E. Standard Test Methods for Fiber Reinforced Concrete; China Planning Press: Beijing, China, 2009.

35. Pu, W.; Zhen, H.; Dai, Z.; Dong, W.X.; Chang, Z. Impact mechanical properties of concrete reinforced with hybrid carbon fibers. J. Vib. Shock 2012, 31, 14-18.

36. Ding, Y.; Li, D.; Zhang, Y.; Azevedo, C. Experimental investigation on the composite effect of steel rebars and macro fibers on the impact behavior of high performance self-compacting concrete. Constr. Build. Mater. 2017, 136, 495-505. [CrossRef]

37. China, S.A.O.T. Common Portland Cement; China Architecture\& Building Press: Beijing, China, 2007.

38. China, S.A.O.T. Lightweight Aggregates and its Test methods-Part 2: Test Methods for Lightweight Aggregates; China Architecture\& Building Press: Beijing, China, 2010.

39. China, M.O.C.O. Standard for Technical Requirements and Test Method of Sand and Crushed Stone (or Gravel) for Ordinary Concrete; China Architecture\& Building Press: Beijing, China, 2006.

40. China, M.O.C.O. Technical Specification for Lightweight Aggregate Concrete; China Architecture\& Building Press: Beijing, China, 2002. 
41. Cheng, S.; Shui, Z.; Yu, R.; Sun, T.; Zhang, X. Multiple influences of internal curing and supplementary cementitious materials on the shrinkage and microstructure development of reefs aggregate concrete. Constr. Build. Mater. 2017, 155, 522-530. [CrossRef]

42. Chen, F.; Zhang, G.; Ding, S.; Qing, M. Half-dry coral sand concrete preparation technology under natural conditions. China Harb. Eng. 2017, 37, 68-72.

43. China, M.O.C.O. Standard for Test Method of Mechanical Properties on Ordinary Concrete; China Architecture\& Building Press: Beijing, China, 2002.

44. ACI Committee 544. Measurement of Properties of Fiber Reinforced Concrete. Materials Journal 1988, 85, 583-593.

45. Li, D.; Tao, J.; Jia, B. Experimental study on the effect of impact resistance of basalt fiber reinforced concrete. New Build. Mater. 2012, 39, 47-51.

46. Ali, M.A.E.M.; Soliman, A.M.; Nehdi, M.L. Hybrid-fiber reinforced engineered cementitious composite under tensile and impact loading. Mater. Des. 2017, 117, 139-149. [CrossRef]

47. Wang, J.; Feng, P.; Hao, T.; Yue, Q. Axial compressive behavior of seawater coral aggregate concrete-filled FRP tubes. Constr. Build. Mater. 2017, 147, 272-285. [CrossRef]

48. Zhang, W.; Chen, S.; Liu, Y. Effect of weight and drop height of hammer on the flexural impact performance of fiber-reinforced concrete. Constr. Build. Mater. 2017, 140, 31-35. [CrossRef]

49. Rahmani, T.; Kiani, B.; Shekarchi, M.; Safari, A. Statistical and experimental analysis on the behavior of fiber reinforced concretes subjected to drop weight test. Constr. Build. Mater. 2012, 37, 360-369. [CrossRef]

50. Murali, G.; Asrani, N.P.; Ramkumar, V.R.; Siva, A.; Haridharan, M.K. Impact resistance and strength reliability of novel two-stage fibre-reinforced concrete. Arab. J. Sci. Eng. 2019, 44, 4477-4490. [CrossRef]

51. AbdelAleem, B.H.; Ismail, M.K.; Hassan, A.A.A. The combined effect of crumb rubber and synthetic fibers on impact resistance of self-consolidating concrete. Constr. Build. Mater. 2018, 162, 816-829. [CrossRef]

52. Chen, X.Y.; Ding, Y.N.; Azevedo, C. Combined effect of steel fibres and steel rebars on impact resistance of high performance concrete. J. Cent. South Univ. 2011, 18, 1677-1684. [CrossRef]

53. Arora, S.; Singh, S.P. Analysis of flexural fatigue failure of concrete made with $100 \%$ coarse recycled concrete aggregates. Constr. Build. Mater. 2016, 102, 782-791. [CrossRef]

54. Nataraja, M.C.; Dhang, N.; Gupta, A.P. Statistical variations in impact resistance of steel fiber-reinforced concrete subjected to drop weight test. Cem. Concr. Res. 1999, 29, 989-995. [CrossRef]

55. Song, P.S.; Wu, J.C.; Hwang, S.; Sheu, B.C. Assessment of statistical variations in impact resistance of high-strength concrete and high-strength steel fiber-reinforced concrete. Cem. Concr. Res. 2005, 35, 393-399. [CrossRef]

56. Badr, A.; Ashour, A.F.; Platten, A.K. Statistical variations in impact resistance of polypropylene fibre-reinforced concrete. Int. J. Impact Eng. 2006, 32, 1907-1920. [CrossRef] 